\section{The health profile of street children in Africa: a literature review}

\author{
Samuel Nambile Cumber, \\ Joyce Mahlako Tsoka-Gwegweni \\ Discipline of Public Health Medicine, \\ Department of Nursing and Public \\ Health, College of Health Sciences, \\ University of Kwazulu-Natal Durban, \\ South Africa
}

\section{Abstract}

The United Nations Children's Fund has labeled street children as children in difficult circumstances, which represent a minority population that has been under-represented for too long in health research. This is a concern because street children are at risk of carrying a greater disease burden. Their homeless lifestyle makes them more vulnerable to health risks and problems than children who live at home; as they roam the streets begging for food and money to obtain basic needs and are found sleeping in half-destroyed houses, abandoned basements, under bridges and in the open air. This paper presents health results from a systematic review of literature from 17 databases and including 16 countries in Africa. The review revealed that there are more boys than girls living on the street in their adolescence and who mainly have left home due to poverty and abuse. These children in these countries are vulnerable to poor health due to factors such as homelessness, risky sexual behavior, substance abuse and violence. Among the health problems identified are growth and nutritional disorders, physical injuries, violence, sexual abuse, communicable diseases including diarrheal diseases, malaria, respiratory diseases, neglected tropical diseases, mental health issues, substance abuse, reproductive health disorders, mortality, sexually transmitted diseases and HIV/AIDS. Primary interventions that could prevent poor health and improve the health status of street children include provision of safe shelter, proper nutrition, access to health care, health education, and sexual reproductive health, protection from any form of abuse, violence and substance abuse. Enforcing state policies and laws in all African countries is required to protect street children from neglect, abuse and to increase their access to education. More research on the health risks and health status of street children is still required, particularly in Sub-Saharan Africa, which carries the greatest disease burden and poverty.

\section{Introduction}

The United Nations Children's Fund (UNICEF) has labeled street children as children in difficult circumstances, which represent a minority population and have been under-represented for too long in health research. The street child population has also been categorized into two overlapping groups: i) of-the-street children, who are children having no contact with family and hardly ever return home and ii) on-the-street children, who often sleep at home but are based on the street during the day. ${ }^{1,2}$ This is a concern because they also bear a greater disease burden. ${ }^{3}$ Their vulnerability on the streets places them at high risk of experiencing health problems. Many factors have been identified to contribute to their vulnerability to poor health. However, engaging this population in health research has been shown to present unique challenges such as participant enrolment and ethical issues. ${ }^{4,5}$ Street children have been shown to roam the streets of urban areas begging and looking for jobs in order to obtain food and other basic necessities. ${ }^{6,7}$ They usually work in poor conditions, dangerous to their health, and starve some days. Street children are reported to often be found in busy places such as railway stations, bus stations, in front of film or night clubs, with no adult supervision, sleeping in half-destroyed houses, abandoned basements, under bridges and in the open air., $3,8-14$ Developmental and health-related problems experienced during childhood affect street children in the present and are likely to follow them into adulthood. ${ }^{4,5}$

African countries have many good national laws and some are specifically aimed at street children, but these policies are often not properly implemented or evaluated. ${ }^{11,13}$ According to UNICEF, the street children phenomenon presents one of the most complex challenges in low- and middle-income countries for policy makers today.

\section{Materials and Methods}

In this literature review of the health profile of street children in Africa, 17 data bases, namely; EBSC0, PubMed, Web of Science, ArticleFirst, ECO, PsycINFO, Africa Bibliography, Bibliography of Africana periodical Literature, African Journal On-Line, CINAHL, DIVA, Education Resources Information Centre, Google Scholar, LIBRIS, GenderWatch, SwePub and TOXNET, were searched for articles, journals and reports from international and national organizations, including non-governmental organizations. The literature was published from 1990 to 2015
Correspondence: Samuel Nambile Cumber Discipline of Public Health Medicine, Department of Nursing \& Public Health, College of Health Sciences, University of Kwazulu-Natal Durban, South Africa

E-mail: samuelcumber@yahoo.com

Key words: Street children; Africa; Health.

Contributions: the authors contributed equally.

Conflict of interest: the authors declare no potential conflict of interest.

Received for publication: 14 June 2016. Accepted for publication: 13 July 2016.

This work is licensed under a Creative Commons Attribution NonCommercial 3.0 License (CC BYNC 3.0).

(C) Copyright S. N.Cumber

and J. M. Tsoka-Gwegweni, 2015

Licensee PAGEPress, Italy

Journal of Public Health in Africa 2015; 6:566 doi:10.4081/jphia.2015.566

and 1437 citations were found, using keywords such as street children, street kids, street youths, homeless children, health and Africa.

The study included 16 African countries, namely Botswana, Cameroon, Democratic Republic of Congo, Egypt, Ethiopia, Ghana, Kenya, Nigeria, Rwanda, Senegal, South Africa, Sudan, Tanzania, Tunisia, Uganda and Zimbabwe. Publications were eliminated if they were not in English or French, if they included youths older than 18 years of age, if the participants were youths in refugee camps and if they did not provide original data.

\section{Results and Discussion}

Specific socio-demographic characteristics were collected and the most frequently health outcomes found were growth and nutritional disorders, physical injuries, parasitic and other community-acquired infectious diseases, sexual and reproductive health disorders, violence and sexual abuse, substance use and abuse, mental health problems access to health care services and transactional sex practice and its consequences. Considerations about structural factors and health accessibility have been found.

\section{Socio-demographic characteristics}

The street child population reported in the studies constituted both male and female participants. A number of studies from southern and North Africa (Egypt) showed mostly boys on the streets, while some from East and West Africa recruited a small number of street girls 
(less than 30\%). The children were usually between the ages of 12 and 17 years, though some West African studies identified street children as young as 7 years old. The studies showed that some street children had little or no contact with their families and most of them lived in dangerous parts of the city such as under bridges, in and around the city markets and other dark places. ${ }^{3,15-19}$ Dropping out from primary school was a general characteristic among the participants (more than 70\% have done so), though some never attended school at all. The reasons for the latter were that families could not afford school fees and that most of the children came from polygamous and big families with an average of 4 to 9 children per household. Most of the studies in southern and West Africa reported that the experiences of street girls were more severe than those of boys. On the other hand, street girls were found to be more amenable than street boys to being recruited to institutions, staying with relatives, being recruited into sex work, being deceived to fall in relationships with older men sugar daddy, making them less visible on the streets than boys. ${ }^{15,16,19-24}$

\section{Growth and nutritional disorders}

Several studies on street children in Africa have documented poor growth and nutritional status by using basic primary measures of body mass index or stunting. Studies from South Africa, Kenya and Egypt have shown that street children had access to nutritional sources as shown on Table 1. Furthermore, a study conducted in Alexandria, Egypt, showed that the number of malnourished and anemic street children was very high, reporting a prevalence of 83 and $78 \%$ for the respective conditions. ${ }^{18,25}$ The studies revealed that street children with strong family ties were more likely to have a better growth outcome than those with little or no family ties. Nutritional disorder was reported in some countries to affect growth and development, predisposing street children to other health problems including chronic diseases, anemia, infections and impaired sight. ${ }^{18,26-28}$ These countries like
South Africa, Kenya, Nigeria and some others do have policies that include street children, but implementing these policies has been a challenge. Our review showed that overconsumption of food, which leads to obesity, is not common among street children in Africa, but that they suffer from anemia due to insufficient iron and impaired sight due to vitamin A deficiency. This damages growth and development of these children and may lead to chronic diseases, infections and many other health problems. ${ }^{26,28}$

\section{Physical injuries}

Physical injuries are reported to be among the leading causes of child mortality, especially among street children. Our review of physical injuries showed a higher rate among street boys than girls and those from the age of 16 years and older are associated with an increased risk of injury on the streets. . $^{3,20,25,29}$ This group is reported to be injury prone because they have emotional, physical, developmental or behavioral characteristics that explain why they are frequently injured. The injuries mostly reported include sprains, cuts, scratches, lacerations, amputations, burns, bruises from street fights and accidents with motorcycles and moving cars. ${ }^{3,20,25}$ Reducing morbidity and mortality among street children, as has been emphasized in some studies, should be a priority and further research is needed to provide a better understanding of why the injury rate is much higher among this population. ${ }^{25,29}$

\section{Parasitic and other community- acquired infectious diseases}

Parasites and other infectious diseases remain a serious public health problem in Africa. Some studies reported that infectious diseases are more prevalent among street children than children who live in homes. Parasitic infections identified to mostly affect street children in Africa are caused by worms as Ascaris lumbricoides and schistosomes, and protozoa as Giardia lamblia and Blastocystishominis. ${ }^{26-28,30-34}$ Tuberculosis, pneumonia and malaria, as major infectious diseases, were reported to be among the leading causes of morbidity and mortality among street children, with a higher prevalence of malaria in West Africa, while tuberculosis and pneumonia were highly prevalent in East and southern Africa. ${ }^{26-28,30-33}$

\section{HIV/AIDS and sexually transmitted infections}

Sexual transmitted infections (STIs) like gonorrhea including HIV/AIDS among street children have been reported as being very high and some studies showed that it can be higher than that of female sex workers, truck drivers and prisoners. This is a significant reason for why this population should be attended to immediately, providing necessary intervention to help educate this group of children about the dangers and consequences of unprotected sex, STIs and HIV infection. ${ }^{35,36}$ HIV knowledge is limited among most street children as most obtain information about HIV from their peers. Only a few of the respondents knew that the primary mode of HIV transmission is by unprotected sex. Many street children were already sexually active and most of them mainly cited satisfying their bodily needs as a reason. Furthermore, condom use is still very low among both male and female respondents. ${ }^{35,36}$ Some studies, as shown in Table 2, highlighted that most street children have heard of HIV, but engaged in unprotected sex nonetheless, having multiple partners, with some being involved in sex work. ${ }^{4,6,8,37}$ Some major risk factors for STIs and HIV/AIDS among street children are transactional sex, violence, sexual abuses and multiple sexual partners. Transactional sex is a term often being use with regards to children and youths than survival sex to express the style of exchanging sex for material needs, while survival sex is used as a work style and prostitution as work in poverty. ${ }^{21,38,39}$ Literature reported that transactional sex was described by street children as the practice of exchanging sex for their most urgent need at the time, which might be money, shelter, drugs or protection from dan-

Table 1. Nutritional and growth status of street children in Africa.

\begin{tabular}{|c|c|c|c|c|}
\hline Country (city) & Author/year & Sample size (n) & Source & Results \\
\hline $\begin{array}{l}\text { South Africa } \\
\text { (Durban) }\end{array}$ & Nzimakwe $1994^{1}$ & 50 & $\begin{array}{c}\text { Shelter/ } \\
\text { place of safety }\end{array}$ & $\begin{array}{l}\text { Girls: All above the third percentile for weight; } 60 \% \text { below the third } \\
\text { percentile for height. } \\
\text { Boys: } 37.5 \% \text { below the third percentile for weight; } 62.5 \% \text { below the } \\
\text { third percentile for height. } \\
\text { Malnutrition: } 20 \% \text { girls; } 27.5 \% \text { boys. }\end{array}$ \\
\hline $\begin{array}{l}\text { Kenya } \\
\text { (Eldoret) }\end{array}$ & $\begin{array}{l}\text { Ayaya } \\
2001^{2}\end{array}$ & 191 & $\begin{array}{l}\text { Street (snowball sample); } \\
\text { school case control }\end{array}$ & $\begin{array}{l}\text { Shelter and on-the-street children more likely to be } \\
\text { undernourished than of-the-street or school children ( } 64.3,55.3 \text {, } \\
27.7 \text { and } 20 \% \text { respectively), as well as more stunted (51.8, 44.7, } 17.4 \\
\text { and } 20 \% \text { respectively). }\end{array}$ \\
\hline Egypt (Alexandria) & Salem $2002^{3}$ & 100 & Street shelter & $83 \%$ malnourished (wasting and stunting) and 78\% anaemic. \\
\hline
\end{tabular}


gers on the streets, and these practices were most prevalent among street girls and among of-the-street children. ${ }^{20,21,38-41}$

\section{Sexual and reproductive health dis- orders (adolescent pregnancy and mortality)}

There are limited studies on the sexual reproductive health of street children in Africa. The few studies that were found revealed that street children reported sexual initiation from the ages of 10 to 16 years. Most of the studies from South Africa reported an initiation range from ages 8 to 14 years and that of-the-street children were more sexually active than onthe-street children. ${ }^{19,21}$ Table 2 shows four studies of self-reported history of STIs among street children. The prevalence rate for gonorrhea, syphilis and genital herpes ranged from 2 to $22 \%$ among respondents. . $^{19,21,39,42}$

No studies were found that specifically covered the issue of pregnancy and mortality. However, unwanted pregnancy remains a significant issue with very little information regarding its prevalence among street children being available. These children have no steady source of income and have limited knowledge on child bearing or childrearing. ${ }^{19,29,39}$

\section{Violence and sexual abuse}

Violence and hostility remain some of the main threats to street children's existence according to evidence from the reviewed studies. The evidence further demonstrated that street children experienced most violence at night and this came from police officers, security guard officers, disturbed street adults and shop owners in the cities. $3,6,15,18,20,25,29,37,42-49$ Some children also experienced some level of violence at home, but this cannot be compared with what street children experience. Children at home may endure maltreatment, often from their parents and often when they were younger than 14 years of age. Street children on the other hand are exposed to community violence because of their continuous working and sleeping on the streets at night. Violence against children is generally accepted in many African cultural settings, strongly rooted in some cultures and social practices, and some government laws turn a blind eye to the plight of children in this regard. ${ }^{33,34}$

Sexual abuse/crime to date has the lowest reporting rates compared to that of other crimes. Some authors believe that this might be due to the stigma attached to sexual abuse. Only estimates of the rate of sexual abuse are given, based on those transgressors who have been arrested. All researchers agreed that it is only a small fraction of sexual offenders who are being apprehended. ${ }^{38-40,44,45,50}$ This study could not find the distribution rate of sexual abuse among African street children. Evidence based on self-reports by most street children from studies conducted in East Africa and South Africa showed a high rate of rape and all forms of sexual abuse, but reported a higher prevalence in street girls than boys. ${ }^{38-40,44,45,50}$ From all the reviewed studies on sexual abuse among street children in Africa, children generally reported being sexually abused by street adults, peers, employers and officers who use their authority to compel street children to engage in unwanted sexual activities at their exposed sleeping places at night. This could be the reason why over $50 \%$ of street girls in these studies reported that their first sexual experience was either rape or forced sex at night on the streets. ${ }^{38-40,44,45,50}$ There were several reports by street children accusing the authorities who should be there to protect them. The rate of police abuse towards street children in Africa, however, remains unknown. ${ }^{38,39}$

High rates of sexual abuse were suspected for southern and East Africa, but researchers have reported difficulties in assessing the rate of sexual abuse, as this can only be obtained from forensic data looking at the sample of those who have been arrested and convicted for sexual abuse. Only a small number of the offenders have been arrested and convicted as it is difficult for street children to report the offenders for a number of reasons, e.g. author- ities not taking them seriously and especially street girls being seen as prostitutes. ${ }^{38,39,44}$

\section{Substance use and abuse}

Psychoactive substance use and abuse among street children was reported in most of the literature and prevalence ranged from 35 to $100 \%$. The age of initiation was between 10 and 13 years for street children who commonly use and abuse substances such as alcohol, cigarettes, inhalants, cocaine, marijuana, amphetamines, heroin, shoemakers glue, correction fluid, paint thinner and coca paste, with a higher prevalence reported among ofthe-street children than on-the-street children. ${ }^{44,50-52}$ Street children in South Africa, Nigeria and Kenya showed a high substance abuse rate (Table 3 ). These countries have policies on drug abuse and punishment for those selling drugs to minors, but the policies have not been implemented as drugs are being sold on the roadside, enabling street children to purchase psychoactive substances. ${ }^{44,51,52}$

The reasons given by street children for using psychoactive substances included coping and fitting into street life circumstances, boldness to withstand violence, survival sex, pleasure, to curb hunger, to induce sleep, to numb emotions and for entertainment. $17,20,25,51$ of concern is the fact that these children use the little money they earn on the street to buy substances because they are cheaper than food. ${ }^{52-}$ ${ }^{54}$ Factors associated with psychoactive substance abuse among street children included male gender, depression, lack of family contact, survival sex, unprotected sex, multiple sexual partners, early sexual debut, mini theft, street fights and STIs, thus the duration of time spent on the street worsens the situation. . $^{21,25,44,51,52}$

\section{Mental health problems}

Only a small number of non-ethnographic studies have addressed mental health issues of street children in Africa despite the fact that they are considered as a vulnerable population

Table 2. Sexually transmitted infections and HIV in street children in Africa.

\begin{tabular}{|c|c|c|c|c|}
\hline Country/city & Author/year & Sample size (n) & Source/data source & Prevalence of STIs \\
\hline South Africa (Cape Town) & Seager $2010^{4}$ & 305 & Street/self-report & 5.5\% (past year STI self-reported); HIV: 19.1\% = 6.3 million people. \\
\hline Nigeria (Ibadan) & Olley $2006^{5}$ & 169 & Street/self-report & $\begin{array}{l}\text { Overall: } 21.7 \% \text { (history based on self-reports); } \\
\text { Gonorrhoea: 14.2\%; Syphilis: 5.3\%; Chancroid: } 0.5 \% \text {; Herpes: } 1.7 \%\end{array}$ \\
\hline Nigeria (Ibadan) & Owojae 20096 & 818 & Street/self-report & $\begin{array}{l}\text { Vaginal discharge: } 7.7 \% \text { (past year); } \\
\text { Genital/genital ulcer: 4.2\%; HIV: } 3.34 \%=3.2 \text { million people. }\end{array}$ \\
\hline Kenya (Eldoret) & Ayaya $2001^{2}$ & 191 & $\begin{array}{l}\text { Street, shelter, } \\
\text { school/physical exam }\end{array}$ & Diagnosed with an STI: 2.6\%; HIV: 6.1\% = 1.6 million people. \\
\hline $\begin{array}{l}\text { Zimbabwe } \\
\text { (Harare, Bulawayo, } \\
\text { Mutare, Gweru, Kadoma) }\end{array}$ & UNICEF $2001^{40}$ & 260 & Street & $\begin{array}{l}\text { STI (self-reported): } 14.3 \% \text { of-the-street children and children } \\
\text { sleeping both at homeland on the street more likely than on-the } \\
\text { street children to report STI history (16.5, } 22.2 \text { and } 5.2 \% \\
\text { respectively). HIV: } 15 \%=1.4 \text { million people. }\end{array}$ \\
\hline
\end{tabular}


that suffers from adult exploitation in all forms, poor quality of life and stress, often leading to mental health problems. ${ }^{19,43}$ Their behaviors were frequently reported in the literature, but diagnostic criteria were not described and testing tools were not validated. ${ }^{19,28,42,43}$ Studies on mental health in West and East Africa reported traumatic experiences among street children, but different methodologies were used, making it difficult to compare the results. These studies found that some street children were more likely to report feelings of hopelessness and the general suicide rate among street children was reported to be relatively low at around $2 \%$ among the street children population; female street children in particular were more susceptible. ${ }^{19,28,42,43}$ Taib and Ahmad in their study in 2014 identified particular psychiatric disorders in street children like schizophrenia and others. ${ }^{55}$ The following psychiatric disorders among street children in Africa were reported: depression, hopelessness and suicide ideation, among others. Risk factors like stress and trauma faced by street children were only described in the studies and no standardized diagnostic tools were used in measuring post-traumatic stress disorder, which was described in the studies. Again, these studies used different methods making comparison of the results difficult, but there was agreement in that street children who are more exposed to stressors are more at risk of depression, hopelessness and self-harm, which can eventually lead to suicide if immediate intervention is not provided. ${ }^{19,28,42}$

\section{Structural factors affecting \\ the health of street children}

Reports revealed the complexity of push and pull factors that pose a risk to the health of street children (poverty, divorce, separation of parents, death of one or both parents, economic decline, single-parent households, child abuse, neglect, alcohol abuse, school dropout, family size and traditional values) and while on the streets they become victims of circumstances. ${ }^{9}, 16,17,20,22,29,30,39,56-58$ of the economic activities, $98 \%$ of street children are marginal jobs (survival jobs) that do not require technical knowledge. Such jobs include washing cars, collecting garbage, cleaning shops, begging, shining shoes, carrying luggage, loading/offloading goods, selling newspapers, collecting plastics from waste bins to sell to recycling companies, selling other items such as tissue paper, working as shop boys when there is a demand for manpower, prostitution and dancing in night clubs/bars. ${ }^{9,16,17,20,22,56}$ Considering the lifestyle of street children, societal perspectives are the reasons behind their denial of certain basic needs. These children's efforts towards the satisfaction of basic needs are, therefore, more difficult compared to children under adult supervision and who are well cared for

\section{Access to health care services by street children}

Literature reported little or no access to health care due to high hospitalization and consultation costs in health care facilities, which is a major barrier for street children who earn little or nothing on the streets. Other barriers included stigmatization by health care providers, minority status and not being sure of the quality of care they will receive in health care centers due to their disadvantaged status. The reports further stated that some street children could not find time to visit health care centers as they struggle during the day to raise money for food and other basic necessities and are only free at night. ${ }^{28,32}$ More research is needed in this area since our searched yielded only two studies.

\section{Strength and limitations}

The current review provided a global vision of the health profile of street children in $\mathbf{1 6}$ African countries. Moreover, the review serves as a basis for future research on street children in other African countries as it highlighted gaps in the literature about certain health conditions and the fact that many studies are outdated. The selection of studies that were published in English and French only is another limitation, as is the fact that only 17 databases were searched. Lastly, the search terms that were used could have left out important articles. However, publications regarding some health issues could not be found within the selected journals and included unwanted pregnancy and mortality, which are believed to be serious challenges faced by street children.

Table 3. Substance use in street children in Africa.

\begin{tabular}{|c|c|c|c|c|}
\hline Country/city & Author/year & Sample size (n) & Results & Prevalence \\
\hline $\begin{array}{l}\text { Egypt (Cairo, } \\
\text { Alexandria) }\end{array}$ & Nada $2010^{7}$ & 857 & $\begin{array}{l}\text { Current drug use higher } \\
\text { among males than females }\end{array}$ & Life time drug use: $62 \%$; Current drug use: $51 \%$ \\
\hline Egypt (Assiut) & Elkoussi $2011^{8}$ & $\begin{array}{r}\text { Da } \\
\text { in }\end{array}$ & $\begin{array}{l}\text { aily substances as reported were } \\
\text { nhalants, any other substances, } \\
\text { prescription drugs, marijuana, } \\
\text { hashish and opium }\end{array}$ & $\begin{array}{l}\text { Daily use of substances; Inhalants: } 90.8 \% \text {; } \\
\text { Other substances: } 75 \% \text {; Prescription drugs: 45.8\%; } \\
\text { Marijuana: 25.0\%; Hashish: 20.8\%; Opium: } 7.5 \%\end{array}$ \\
\hline Nigeria (Ibadan) & Morakinyo $2003^{9}$ & $\begin{array}{r}\text { Lif } \\
\text { co } \\
\text { men } \\
\text { asso }\end{array}$ & $\begin{array}{l}\text { fetime/past month use of heroin, } \\
\text { caine. Introduced to substances } \\
\text { by friends (39.9\%) and family } \\
\text { mbers (33.3\%). Time on the street } \\
\text { ciated with current substance use }\end{array}$ & $\begin{array}{l}\text { Substances used in the past month: } \\
\text { Any substance: } 45 / 42.2 \% \text {; Inhalants: } 0.6 / 0 \% \text {; } \\
\text { Tobacco: } 14.4 / 10.0 \% \text {; Marijuana: } 10.0 / 7.8 \%\end{array}$ \\
\hline Ethiopia (Addis Ababa) & Lalor 199910 & $\mathrm{Cc}$ & $\begin{array}{l}\text { Lifetime/weekly/ } \\
\text { daily use of substances. } \\
\text { ommonly used substances were } \\
\text { tobacco, benzene and others }\end{array}$ & $\begin{array}{l}\text { ETOH: } 16.4 / 2.4 / 1.6 \% \text {; Tobacco: } 5.5 / 0.1 / 3.2 \% \text {; Benzene: } \\
\text { 2.5/0.1/0.2\%; Other: } 7.9 / 0.4 / 0.2 \%\end{array}$ \\
\hline Kenya (Eldoret) & Ayaya $200^{12}$ & 91 Repor & $\begin{array}{l}\text { rted use of inhalants (glue), ETOH, } \\
\text { tobacco, marijuana and cocaine }\end{array}$ & $\begin{array}{l}\text { Inhalant (glue): 31.2\%; ETOH: 18.3\%; Tobacco: 37.6\%; } \\
\text { Marijuana: } 8.3 \% \text {; Cocaine: } 4.6 \%\end{array}$ \\
\hline Sudan (Khartoum) & Kudrati $2008^{11}$ & 432 & $\begin{array}{l}\text { Lifetime use (male/female): } \\
\text { mostly glue and tobacco }\end{array}$ & Glue: 70/69\%; Tobacco: 63/63\% \\
\hline South Africa (Cape Town) & Seager $2010^{4}$ & in & $\begin{array}{l}\text { Lifetime use: any drug } \\
\text { the past } 3 \text { months included glue, } \\
\text { trol, marijuana, heroin and other }\end{array}$ & $\begin{array}{l}\text { Any drug: 37\%; Glue and petrol: 25.9\%; Marijuana: 23.3\%; } \\
\text { Heroin: } 2.6 \% \text {; Other: } 4.6 \%\end{array}$ \\
\hline
\end{tabular}

ETOH, ethanol. 


\section{Conclusions}

Street children in the selected countries are vulnerable to poor health due to factors such as homelessness, risky sexual behavior, substance abuse and violence. Primary interventions that could prevent poor health and improve the health status of street children include provision of safe shelter, proper nutrition, access to health care, health education, education about sexual reproductive health, protection against any form of abuse, violence and substance abuse, thus enforcing state policies and laws about street children in all African countries is very important.

Violence and injuries are frequent health problems among street children and place a great burden on their health. More regulations should be made regarding traffic and the availability of emergency first aid services to street children. The prevalence of unwanted pregnancy and mortality and the current situation regarding these issues among street children in Africa is unknown and more information is urgently needed. Further research on the health risks and health status of street children is also required, particularly in SubSaharan Africa, which carries the greatest disease burden.

A detailed review of literature on the health profile of street children comparing the four regions of Africa, namely the North, South, West and East is recommended; given the political, cultural, religious and structural differences between these regions.

\section{References}

1. Kaime-Atterhög W, Ahlberg BM. Are street children beyond rehabilitation? Understanding the life situation of street boys through ethnographic methods in Nakuru, Kenya. Child Youth Serv Rev 2008;30:1345-54.

2. Glauser B. Street children: deconstructing a construct. In: James A, Prout A, eds. Constructing and reconstructing childhood: Contemporary issues in the sociological study of childhood. Oxford: Routledge Falmer; 1990. pp 138-56.

3. UNICEF. The state of the world's children, 2012: Excluded and invisible: United Nations Publications Report No. 9280639161 .

4. Boakye-Boaten A. An examination of the phenomenon of street children in selected communities in Accra-Ghana. Degree Diss., Ohio University, USA; 2006.

5. UNICEF. The state of the world's children, 2011: Adolescence, an age of opportunity. Available from: http://www.unicef.org/pub- lications/index_57468.html.

6. UNICEF. The state of the world's children 2006: Excluded and invisible. Available from: http:/www.unicef.org/ publications/ index_30398.html.

7. UNICEF. Convention on the Rights of the Child. 1990. Avalable from: http://www.unicef. org/crc/.

8. UNICEF. Street and unsupervised children of Africa; 2003. Available from: http://www.unicef.org.

9. UNICEF. Executive Board. Exploitation of working children and street children. U.N. Doc. E/ICEF/1986/CRP. 1990.

10. WHO. World Health Organization. Programming for adolescent health and development. WHO technical report series no. 886. Report of WHO/UNFPA/UNICEF Study Group on Programminlg for Adolescent Health; 1999.

11. United Nations. Convention on the rights of the child. Geneva: UN; 2006.

12. World Bank. How we classify countries. 2012. Available from: http://data.worldbank.org/about/country-classifications.

13. UNICEF. Social protection to tackle child poverty in Ghana Briefing Paper: Social Policies. Dakar: UNICEF and UNICEF Ghana. 2009.

14. UNICEF. The state of the world's children: Excluded and invisible: United Nations Publications Report No: 9280639161; 2012.

15. McAlpine K, Henley R, Mueller M, et al. A survey of street children in Northern Tanzania: how abuse or support factors may influence migration to the street. Community Ment Health J 2010;46:26-32.

16. Beyene Y, Berhane Y. Characteristics of street children in Nazareth, Ethiopia. East Afr Med J 1997;74:85-8.

17. Women Education Researchers of Kenya (WERK) for SNV/Kenya and German Technical Organization (GTZ). The story of children living and working on the streets of Nairobi. 2002.

18. Salem EM, El-Latif FA. Sociodemographic characteristics of street children in Alexandria. East Mediterr Health J 2002;8:64-73.

19. Aptekar L, Ciano-Federoff LM. Street children in Nairobi: gender differences in mental health. New Dir Child Adolesc Dev 1999;85:35-46.

20. Kudrati M, Plummer ML, Yousif ND. Children of the Sug: a study of the daily lives of street children in Khartoum, Sudan, with intervention recommendations. Child Abuse Negl 2008;32:439-48.

21. Olley B0. Social and health behaviors in youth of the streets of Ibadan, Nigeria. Child Abuse Neglect 2006;30:271-82.

22. Lugalla JLP, Mbwambo JK. Street children and street life in urban Tanzania: the culture of surviving and its implications for children's health. Int J Urban Reg Res 1999;23:329-44.

23. Lalor K, Taylor M, Veale $A$, et al. Victimisation among street children in Sudan and Ethiopia: a preliminary analysis. In del Frate AA, Zvekic U, van Dijk JJ eds., Understanding crime: Experiences of crime and crime control. Rome: United Nations Crime and Justice Research Institute publication; 1993. pp 343-9.

24. Young L. Journeys to the street: the complex migration geographies of Ugandan street children. Geoforum 2004;35:471-88.

25. Nada KH, Suliman el DA. Violence, abuse, alcohol and drug use, and sexual behaviors in street children of Greater Cairo and Alexandria, Egypt. AIDS 2010;24:S39-44.

26. Nzimakwe D, Brookes H. An investigation to determine the health status of institutionalised street children in a place of safety in Durban. Curationis 1994;17:2731.

27. Greksa LP, Rie N, Islam AB, et al. Growth and health status of street children in Dhaka, Bangladesh. Am J Hum Biol 2007;19:51-60.

28. Ayaya SO, Esamai FO. Health problems of street children in Eldoret, Kenya. East Afr Med J 2001;78:624-9.

29. Bar-on A. Criminalising survival: images and reality of street children in Botswana. J Social Policy 1997;26:63-78.

30. Gregson S, Nyamukapa CA, Garnett GP, et al. HIV infection and reproductive health in teenage women orphaned and made vulnerable by AIDS in Zimbabwe. AIDS Care 2005;17:785-94.

31. Russell S. The economic burden of illness for households in developing countries: a review of studies focusing on malaria, tuberculosis, and human immunodeficiency virus/acquired immunodeficiency syndrome. Am J Trop Med Hyg 2004;71:147-55.

32. Anarfi JK. Vulnerability to sexually transmitted disease: street children in Accra. Health Transit Rev 1997;7:281-306.

33. Dehne KL, Reidner G. Sexually transmitted infections among adolescents. In: Berer M, ed. The need for adequate health services. Geneva, Switzerland: WHO; 2005.

34. Kayembe PK, Mapatano MA, Fatuma AB, et al. Knowledge of HIV, Sexual Behaviour and Correlates of Risky Sex Among Street Children in Kinshasa, Democratic Republic Of Congo. East African Public Health Ass 2008;5:186-92.

35. Mudingayi A, Lutala P, Mupenda B. HIV knowledge and sexual risk behavior among street adolescents in rehabilitation centres in Kinshasa; DRC: gender differences. Pan Afr Med J 2011;10:23.

36. Asante K0, Meyer-Weitz A, Petersen I. Correlates of psychological functioning of homeless youth in Accra, Ghana: a cross- 
sectional study. Int $\mathbf{J}$ Mental Health Syst 2015;9:1.

37. UNICEF. 2001 ZIM: A study on street children in Zimbabwe. Available from: http://www.unicef.org/evaldatabase/index 14411.html.

38. Anarfi JK. Street youth in Accra city: sexual networking in a high-risk environment and its implications for the spread of HIV/AIDS. Health Trans Rev 1995;5:131-52.

39. Owoaje E, Uchendu 0. Sexual risk behaviour of street youths in southwest Nigeria. East Afr J Public Health 2009;6:274.

40. Wutoh AK, Kumoji EK, Xue ZY, et al. HIV knowledge and sexual risk behaviors of street children in Takoradi, Ghana. AIDS Behav 2006;10:209-15.

41. Ntozi JP, Najjumba IM, Ahimbisibwe F, et al. Has the HIV/AIDS epidemic changed sexual behaviour of high risk groups in Uganda? Afr Health Sci 2003;3:107-16.

42. Seager JR, Tamasane T. Health and wellbeing of the homeless in South African cities and towns. Develop S Africa 2010;27:63-83.

43. Duyan V. Relationships between the sociodemographic and family characteristics, street life experiences and the hopelessness of street children. Childhood 2005;12:445-59.
44. Nada KH, Suliman EDA. Violence, abuse, alcohol and drug use, and sexual behaviors in street children of Greater Cairo and Alexandria, Egypt. AIDS 2010;24:S39.

45. Ikechebelu JI, Udigwe G0, Ezechukwu CC, et al. Sexual abuse among juvenile female street hawkers in Anambra State, Nigeria. Afr J Reprod Health 2008;12:111.

46. Hosny G, Moloukhia TM, AbdElsalam G, et al. Environmental behavioural modification programme for street children in Alexandria, Egypt. East Mediterr Health J 2007;13:1438-48.

47. Ribeiro M0. Street children and their relationship with the police. Int Nurs Rev 2008;55:89-96.

48. Veale A, Donà G. Street children and political violence: a sociodemographic analysis of street children in Rwanda. Child Abuse Neglect 2003;27:253-69.

49. Matchinda B. The impact of home background on the decision of children to run away: the case of Yaounde City street children in Cameroon. Child Abuse Neglect 1999;23:245-55.

50. Hillis SD, Zapata L, Robbins CL, et al. HIV seroprevalence among orphaned and homeless youth: no place like home. AIDS 2011;26:779-92.

51. Morakinyo J, Odejide AO. A community based study of patterns of psychoactive substance use among street children in a local government area of Nigeria. Drug Alcohol Depend 2003;71:109-16.

52. Elkoussi A, Bakheet S. Volatile substance misuse among street children in upper Egypt. Substance Use Misuse 2011;46:359.

53. Olgar S, Oktem F, Dindar A, et al. Volatile solvent abuse caused glomerulopathy and tubulopathy in street children. Hum Exp Toxicol 2008;27:477-83.

54. Thiesen FV, Noto AR, Barros HMT. Laboratory diagnosis of toluene-based inhalants abuse. Clin Toxicol 2007;45:55762.

55. Taib NI, Ahmad A. Psychiatric morbidity among street children in duhok. Clin Med Insights Pediatr 2014;8:11-6.

56. Grundling J, Grundling I. The concrete particulars of the everyday realities of street children. Human Relations 2005;58:173.

57. Apt NA, Blavo EQ. Ghana. In: Mayadas NS, Elliott D, Watts TD, eds., International handbook on social work theory and practice. London: Greenwood Press; 1997. pp 320-43.

58. Gugler J. Ali Zaoua: the harsh life of street children and the poetics of childhood. J North African Stud 2007;12:369-79. 